\title{
Socio Economical Impact Analysis and Adaptation Strategy for Coastal Flooding Case Study on North Jakarta Region
}

\author{
Dede Yuliadi", Eriyatno ${ }^{\#}$, M. Yanuar J. Purwanto ${ }^{\#}$ I Wayan Nurjaya ${ }^{\#}$

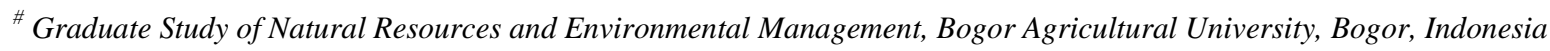 \\ E-mail:deyulose@gmail.com
}

\begin{abstract}
Jakarta landscape was predicted under sea level after 20 years, hence vulnerable for coastal flooding (Rob). According to ALOS/PALSAR image model, land subsidence is around $10 \mathrm{~cm}$ per year. Furthermore, degradation of living environment due to rapid population growth makes Rob area widened. This research aims to analyze socio-economical impact of Rob occurences which covers risk elements of destruction, vulnerability and adaptation capability. The study area in North Jakarta was divided into three clusters according its Rob characterization. Sustainability factor analysis was done through Radar Chart interpretation. Livable City Index (LCI) was evaluated by 15 variables. Soft System Methodology (SSM) used to identify Rob adaptive strategy. Main impact of Rob was found on decreasing of people health, especially children $(48 \%)$, and disruption of community economics activities $(37 \%)$. LCI was calculated 2.00 (hazardous) for cluster 1, 2.27 (inconvenience) for cluster 2 and 3.23 (comfortable) for cluster 3 . According to Purposively Activity Map, adaptive strategy for Rob are better city planning policy, maintenance of dams, and flood control rehabilitation. Rob prevention includes settlement spatial arrangement, road and sidewalks, drainage and clean water provision. Community participation is encouraged, especially in relief funds management and garbage disposal at coastal area.
\end{abstract}

Keywords - Coastal flooding (Rob); LCI; SSM; Adaptive Strategy

\section{INTRODUCTION}

Coastal flooding, known as Rob, is cronical problem for community and government agencies in Jakarta which not yet resolved. Jakarta coastal region consist of large trade port, warehouses and huge economical infrastructures. It has densed population and crowded housing which hampered living environment. Nowadays Rob effect becomes excessive due to rising sea level because of climate change and global warming.

Chaussard [1] warned that within 20 years, Jakarta landscape will be lower than sea level. The ALOS/PALSAR image model predicted land subsidence about $10 \mathrm{~cm}$ per year. Abidin [2] estimated by 2050, sea level will increase up to 1.1 meter while land surface decreasing rate at 2.5 meter per year. Those will make widening Rob coverage extensively [3]. Currently, around 40 percent of Jakarta City, approximately 24.000 hectare, is below sea level with many rivers canal, hence vulnerable for periodical flooding. Coupled with fast growth of population, its natural environment is hard to be protected. Rob occurrences produced high degradation on socio economics aspects within densed populated bay areas at northern part of the city [4]. There are still few academic study on the Rob management policy for Jakarta coastal region [5], [6]. Some research focused on Rob technical events but neglected community adaptation efforts. These may lead to misdirection for Rob impact assessment, hence present actions is conducted mostly toward physical development to prevent Rob. This study intend to explore socio-economic analysis of Rob impact in highly populated coastal area.

Previous study [7] about regional government policy on Jakarta bay sustainability management, had practiced participatory approach of key stakeholders to generate intervention strategy and its implementation. The research covers three administrative regions and developed plan to integrate inter-regions efforts. Supono [8] studied northern Jakarta on sustainable spatial planning concerning rehabilitation action related to land reclamation. He applied system analysis, but in valuation of environmental economic did not include disaster parameters, mitigation strategy and unavoidable loss of business opportunity. Living condition factors was not considered yet.

This research investigate Rob impact on community living environment in line with levels of Rob disaster. By examining complexity aspect of socio-economical of Rob impact, this research aim to generate sustainable adaptation system. 


\section{METHOD}

Research method relied on knowledge based system [9] for issues management as future planning [10]. Location of study is Penjaringan district, divided into three cluster according to average Rob level occurrences as shown in Figure 1.

In each clusters, there are at least 15 respondent for socioeconomical survey, selected through purposive sampling. Data collection to estimate Liveable City Index (LCI) was conducted and integrated using Radar Chart as actual evidences graphics [11]. The LCI expressed in Lickert scale, consist of 15 Rob sustainability factors including city planning quality, pollution, road and sidewalk construction, public education and recreational facilities, and clean water provision. Rob disasters impact is also measured against public income and health assurance.

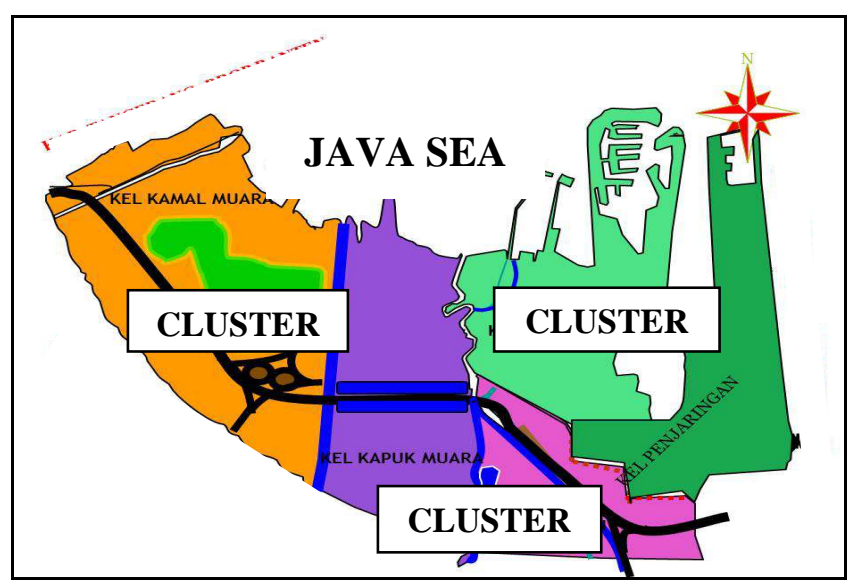

Fig. 1. Clustering of Study Area According to Rob Impact at Penjaringan District, North Jakarta

Cluster 1 : High impact $(1.0-1.5 \mathrm{~m})$

Cluster 2 : Medium impact $(0.5-1.0 \mathrm{~m})$

Cluster 3 : Low impact (0.1-0.5 m)

To design adaptive strategy system to handle Rob impact, this research implementing Soft System Methodology [12], [13] through constructing Rich Picture, Root Definition and Purposively Activity Map (PAM). Expert survey and Focus Group Discussion were conducting involving small groups of capable respondent with various background to ensure its inter disciplinary approach [14], [15].

\section{RESULT AND DISCUSSION}

\section{A. Situational Analysis}

The Kapuk Muara sub-district at cluster I is closed to beach line hence much effected by Rob due to tidal wave. The Penjaringan sub-district occasionally get Rob with minimum damaged by having dams along sea front. In 2014, there was $50 \mathrm{~cm}$ high of Rob which forced 600 inhabitants around Angke River abandoned their homes almost 2 weeks.

The Kamal Muara sub-district at cluster 2 is 3 to $6 \mathrm{~km}$ distance to beach line. Some of this area has border dams to prevent from tidal wave rising, but in November 2012 there was 40 to $60 \mathrm{~cm}$ level of Rob flood which caused hundreds of families left their homes. Drainage control was not properly function, consequently sea water run deep into housing.

The Pluit sub-district at cluster 3 is relatively safe from regular Rob due to long distance from beach and wellprepared infrastructures. But in January 2011, it was sudden high tidal wave that bring this region heavily flooded. Naturally, the impact was quite disturbing daily economic activities because of demolition of road access and transportation.

To have broader picture of yearly Rob situational in northern part of Jakarta, figure 2 shows monthly average frequency as result of time series data processed

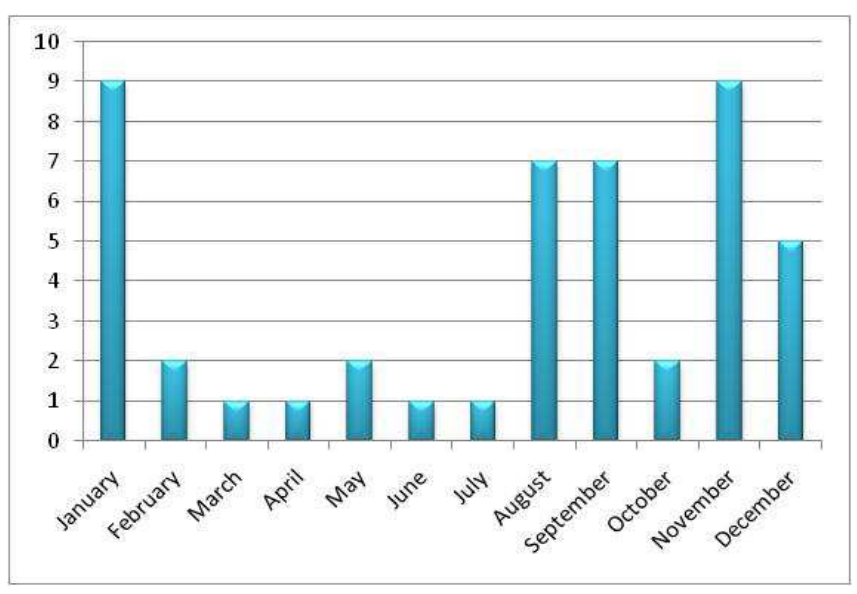

Fig. 2. Rob frequency in Jakarta - North

\section{B. Socio-Economic Impact}

By recent survey, most of community aware about Rob which occur once or twice a year. $60 \%$ of respondent experience that Rob will cease usually within 6 to 24 hours, but its impact prolonged for days afterward.

Garbage pollution is main problem affecting clean water availability and village sanitation. $48 \%$ of respondent got various diseases, especially children. Around $85 \%$ workers, especially fisherman, are out-off work and $92 \%$ suffer from daily income losses. Most of properties and household furniture severely damaged for $81 \%$ of local inhabitants

Those disastrous impact of Rob, has elevated community spirit to take adaptive action collectively. Government support and other community aids has counter those problems, but still not yet satisfactory. Table 1 shows various kind of main adaptive efforts.

TABLE I

ADAPTIVE EFFORT BY LOCAL COMMUNITY

\begin{tabular}{|c|c|}
\hline Community Activities & Government Support \\
\hline 1. Elevate house floor & 1. Supply of water pumps \\
\hline 2. Upstairs construction & $\begin{array}{l}\text { 2. Construction of road } \\
\text { and maintenance }\end{array}$ \\
\hline 3. Elevate road and sidewalks & 3. Elevate main road \\
\hline 4. Waste and garbage disposal & $\begin{array}{l}\text { 4. Water seepage to } \\
\text { prevent flooding }\end{array}$ \\
\hline 5. Social - work & $\begin{array}{l}\text { 5. Strengthening Disaster } \\
\text { Relief Taskforce }\end{array}$ \\
\hline 6. Drainage Repairmen & 6. Providing Disaster \\
\hline 7. Disaster Relief Team & $\begin{array}{ll} & \text { Relief Fund } \\
\text { 7. } & \text { Children Health Care }\end{array}$ \\
\hline
\end{tabular}




\section{Livable City Index}

The Livable City Index (LCI) scaling is 1 to 5, from worst to best living environment. LCI at Penjaringan District was calculated from 15 Rob factors as below:

TABLE III

LCI BY CLUSTER

\begin{tabular}{|l|l|l|l|}
\hline Cluster & Rob Impact & LCI & Description \\
\hline 1 & Heavy & 2.00 & $\begin{array}{l}\text { Severe damage on living } \\
\text { condition }\end{array}$ \\
\hline 2 & Moderate & 2.72 & Sustain by Rob Relief action \\
\hline 3 & Light & 3.33 & $\begin{array}{l}\text { Comfortable with few } \\
\text { impacts }\end{array}$ \\
\hline
\end{tabular}

Cluster 1 may improve their LCI through road establishment with less frequent of Rob event. For cluster 2, normal living will be achieved by doing side-jobs during Rob season, betterment of education and transportation facilities. Comfortable living in cluster 3 is supported by modern health and education facilities including health insurance accessibility.

Characteristic diversity of each cluster can be viewed by Radar Chart (Figure 3).

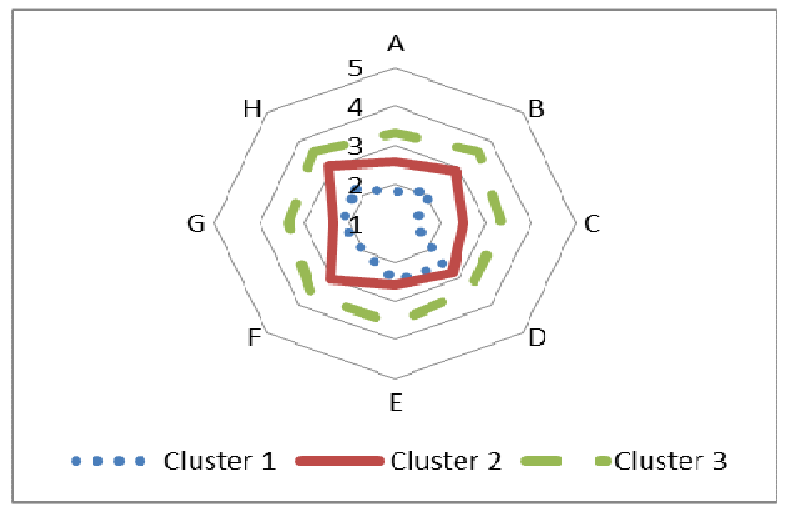

Fig. 3. Radar Chart for Socio-economic Factor of Rob Impact

Note :

A - Sanitation, B - Road, C - Sidewalk, D - Health Facilities,

E - Education Facilities, F - Rob Frequencies,

G - Household Ratio, H - Side Jobs During Rob

Based on interviews, FGD, and field observation, this study conclude that socio-economic problems in Penjaringan District has three strategic Rob issues, i.e. :

a. Spatial planning related to settlement arrangement

b. Drainage and flooding discharge channels

c. Domestic water supply for household

Even though people awareness about Rob impact is high, they have to stay around due to economic factors. Hence, displacements is not favourable solution and enhance resistances.

\section{System Analysis for Adaptive Strategy}

To explore more comprehensive about Rob impact being handled by various stakeholders, SSM was used for systematic analysis. Checkland protocol was followed in constructing Rich Picture, Root Definition and Purposively Activity Map (PAM). The system analysis was based on logical thinking process [16] to perform knowledge management and modelling [17], [18].

1) Rich Picture : To gain overview of stake holders role in Rob adaptive system, Rich Picture was drawn graphically after various in-depth interview with local community leaders and government authorities (see figure 5).

2) Root Definition : Root definition of rob adaptive system is generated after interpreting interaction and need of stakeholders at Rich Picture. Those are :

a) Adaptive system to handle Rob occurrences is joint efforts by community, government agencies and private sector in order to minimize severe impacts that produce environment degradation and decreasing inhabitants standard of living.

b) Adaptive efforts by local community are depend upon people awareness on environmental sustainability concerning infrastructure maintenance, especially road and drainage, and waste disposal so that less disruptive over daily activities and necessity business.

3) Purposively Activity Map (PAM) : Exploration of the root definition was continued with FGD of key stakeholders, mainly local leaders and government authorities, to draw PAM as follows.

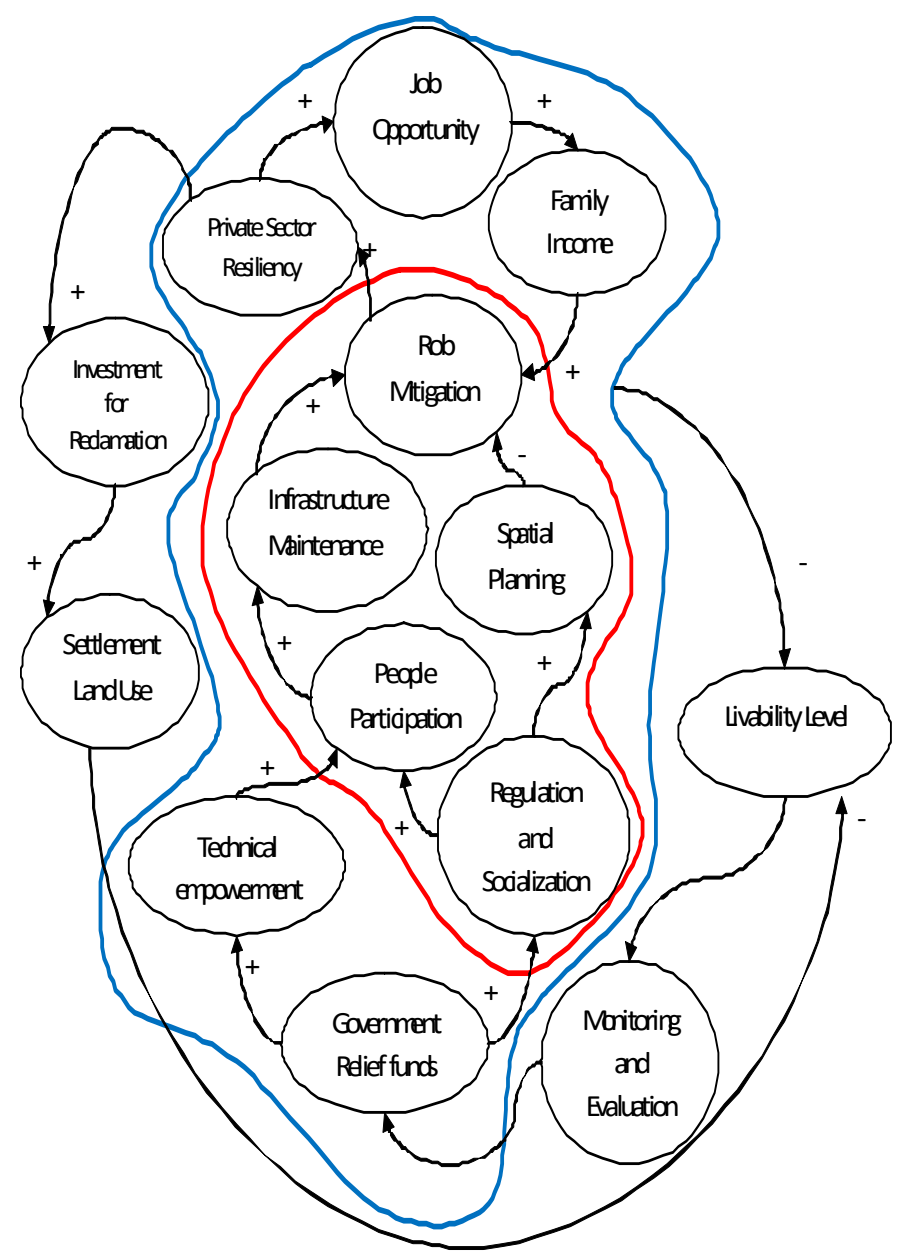

Fig. 4. PAM for Rob Adaptive System 


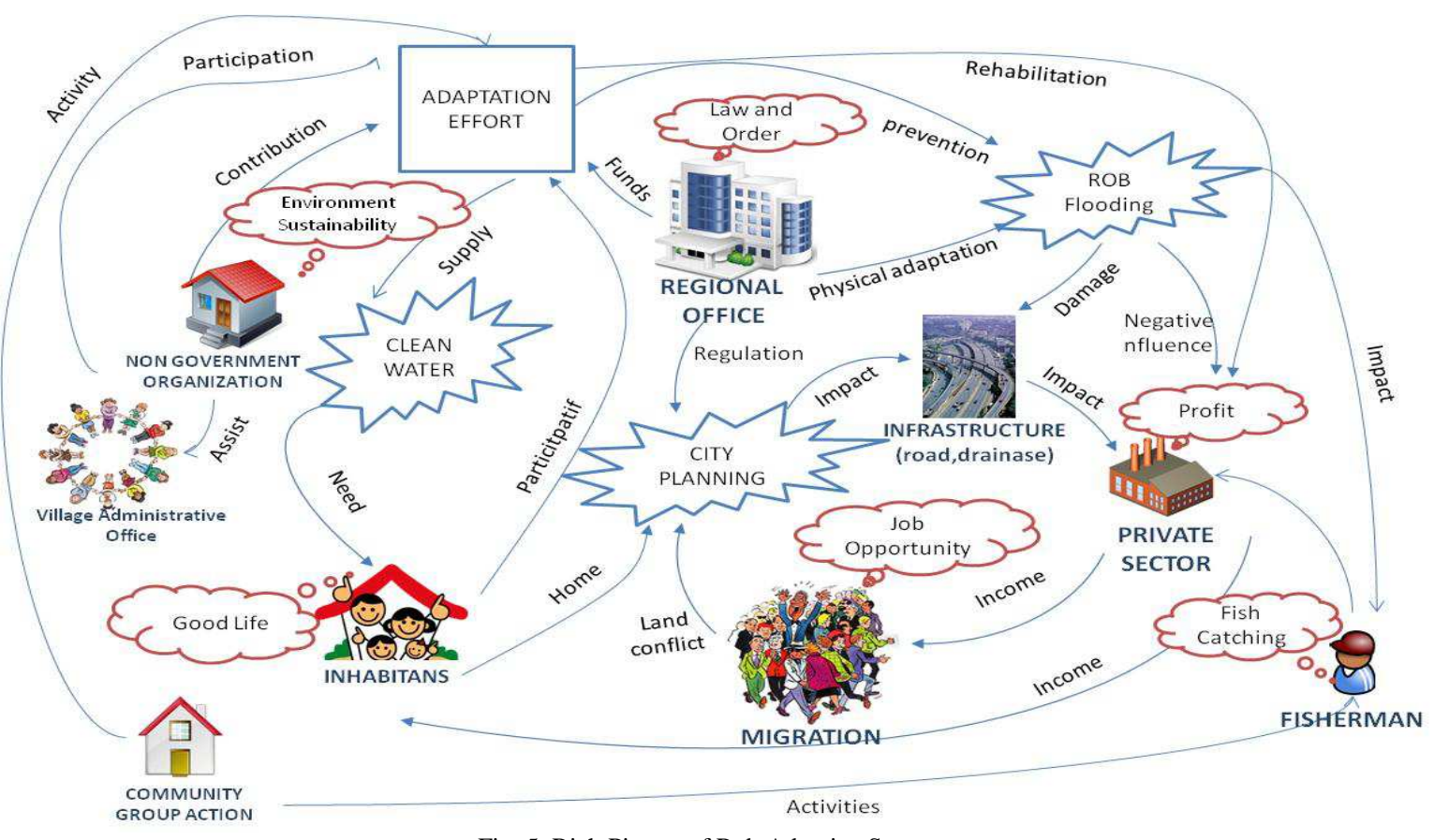

Fig. 5. Rich Picture of Rob Adaptive System

Having examined Rich Picture and PAM, this research indicate the importance of proper regulation imposed by local authorities, as well as public information, in order to improve community participation. Spatial planning and infrastructure maintenance are policy based Rob prevention which should be managed efficiently through stakeholders collaboration. Monitoring and evaluation must be integrated into Rob early warning to ensure quick response in relief purpose.

\section{CONCLUSIONS}

Referring to situational analysis and strategic issues identification, this study has developed policy planning process related to Rob adaption program for coastal urban area. The proposed strategy concerning socio-economic aspect for sustainable livelihood [19], may consist of three activities: (a) Coastal spatial planning expressed on zonation characters by Rob occurrences and reclamation practiced; (b) City drainage and garbage disposal arrangement with active people participation; (c) Clean water for domestic usage to prevent from contamination outbreak because of Rob polluted water.

It is recommended for local government agencies to conduct better disaster management and relief fund management. Early warning system should be installed and executed by responsible local authorities.

\section{REFERENCES}

[1] Chaussard, E., Amelung, F., Abidin, H.Z., Hong, S.H. 2013. Sinking Cities in Indonesia: ALOS/PALSAR Detect Rapid Subsidence due to Groundwater and Gas Extraction. Remote Sensor of Env., 128, 150:161.

[2] Abidin, H. Z., Andreas, H., Gamal, A., Gumilar, A., Napitupulu, M., Fukuda, Y., Debuchi, T.,Maruyama, Y., Riawan, E. 2011. Land Subsident Characteristic of Jakarta Basin and its Relation with
Groundwater Extraction and Sea Level Rise. Ind. Count. Report. IUGG, Melbourne, Australia.

[3] Mori, S, Hattori, M, Matsumoto, J. 2011. The CrossEquabricalNorthernly Surge over The Maritime Continent. Journal of Meteorological Society of Japan. Vol 89A, 27 : 47.

[4] Marfadi, M.A. 2013. Rob Flooding Disaster: A Preliminary Study on Coastal Flooding in Jakarta. Grahallmu Pub., Jogjakarta

[5] Putra, IDNN, Tanaka, T. 2013. Seasonal and Inter-annual Variability of Sea Surface Temperature and Sea Surface Wind in the Eastern Part of Indonesia. Proc. SPIE. 8525.

[6] Berina, D,.Wijayanti, P. 2012. Adaptive Strategy and Cost to Community at Jakarta Basin on Rob Flooding Impacts. PPI Wageningen. A Seminar Paper

[7] Widi, A. P. 2004. Coastal Area Management based on Disaster Mitigation. Bandung Institute of Technology (ITB). Bandung. A Seminar Paper

[8] Supono, S. 2009. Policy Model for Sustainable Northern Jakarta Coastal Area. Bogor Agricultural University. A Dissertation

[9] Walters, J and N. R. Nielsen. 1988. Crafting Knowledge Based Systems. John Wiley \& Sons, Chichester

[10] Coates, J. F. 1986. Issues Management: How to Plan, Organize, and Manage for the Future. Mt. Airy, MD: Lomond.

[11] Mutaqien, D, Djonoputro, B.,Prasetyo, I., Argo, T.A, Mulyanto, D. 2010. Indonesia Most Livable City Index. http://iap.or.id/data/download/MLCI

[12] Checkland, P and J. Scholes. 1990. Soft System Methodologies in Action. John Wiley \& Sons, New York

[13] Jackson, M.C. 2003. System Thinking: Creative Holism for Managers. John Wiley \& Sons, New York

[14] Godet, M. 2006. Creating Futures: Scenario Palnning as a Strategic Management Tool. Economica Pub., Paris.

[15] Eriyatno. 2012. System Science: Increasing Quality and Management Effectiveness. Center for System. GunaWidya Pub., Surabaya Indonesia

[16] Dettmer, H. W. 2007. The Logical Thinking Process: A System Approach to Complex Problem Solving. ASQ Quality Press, Wisconsin

[17] Carrico, M. A. 1989. Building Knowledge Systems. Mcgraw Hill Pub., New York.

[18] Brocklesby, J. and S. Cumming. 1995. Continuing Hard, Soft and Critical Methodologies in System Research: The Cultural Constraints. System Research, Vol 12(3), 329:246

[19] Hart, H. 2006. Sustainable Measures. http://sustainablemeasures.com 